\title{
頭頸部横紋筋肉腫の細胞・分子生物学的診断
}

\begin{tabular}{|c|c|c|c|}
\hline 杉本 & 徹 ${ }^{1)}$ ・細井 & 創 2 • 松村 & 隆文 ${ }^{2)}$ \\
\hline 井 & 千晶2)・峯 & 宏2) • 沢田 & \\
\hline 河田 & $了^{3)}$ - 竹中 & 洋3) - 村上 & \\
\hline
\end{tabular}

\section{Cellular and Molecular Biological Diagnosis of Rhabdomyosarcoma Originating in the Head and Neck}

\author{
Tohru Sugimoto \\ (Miyazaki Medical College)
}

\author{
Hajime Hosoi, Takafumi Matsumura, Chiaki Shirai, \\ Hiroshi Mine, Tadashi Sawada, Ryo Kawata, \\ Hiroshi Takenaka and Yasushi Murakami
}

(Kyoto Prefectural University of Medicine)

\begin{abstract}
Histological differential diagnosis of malignant head and neck tumors in childhood, including malignant lymphoma, neuroblastoma and rhabdomyosarcoma, is occasionally difficult, since these tumors are classified as small-round-cell tumors. Recently we diagnosed and treated four children with rhabdomyosarcoma, originating in the head and neck. In three patients, immunohistological diagnosis using monoclonal antibodies against cytoskeletal proteins led to the accurate diagnosis of rhabdomyosarcoma. In the remaining one patient, the myogenic regulatory gene (MyoD1) RNA expression in the tumor tissue facilitated a final diagnosis of immature rhabdomyosarcoma.

The usefulness of immunohistological and molecular diagnosis of rhabdomyosarcoma is emphasized.
\end{abstract}

Key words : rhabdomyosarcoma, diagnosis, cytoskeletal protein, myogenic regulatory gene (MyoD1)

\section{はじめに}

頭頸部に見られる原発悪性腫瘍は，小児悪性腫瘍の約 $5 \%$ と比較的まれである1). 頭頸部の原発悪性腫瘍には, 悪性リンパ腫, 軟部組織腫瘍, 神経芽腫などがある。軟 部組織腫瘍では横紋筋肉腫が多く, 眼窩, 鼻咽頭, 耳, 乳様突起, 上顎, 舌, 顔面の軟部組織を原発部位とし, 頸部リンパ節転移で発症することがある122).

我々は最近 4 例の頭頸部原発の小児横紋筋肉腫を経験
した.これら 4 症例での横紋筋肉腫の確定診断には, 細 胞骨格蛋白の解析が 3 例で有効であった。 また分子生物 学的手法を用いて検討した筋分化制御遺伝子 $(\mathrm{MyoD} 1)$ 発現が，残りの 1 例で有効であったので報告する.

対象と方法

1) 症 例

当院で経験した頭頸部原発の横紋筋肉腫 4 症例の臨床

1）宮崎医科大学小児科学教室

2) 京都府立医科大学小児科学教室

3）京都府立医科大学耳鼻咽喉科学教室 
像表表 1 亿示す。

(1)症例 ：6 歳女览. 左上顎・鼻腔部腫瘍. 1987年 8 月左鼻閉塞, 9 月に左眼球結膜充血々眼球突出が出現 した. MRI で左上䫇洞に腫瘍を認め, 上顎洞前壁と側 壁に骨欠損，また眼窩に腫瘍の浸潤を認めた。前院での 生検, $\mathrm{HE}$ 染色で小円形細胞腫瘍を認め, 嗅神経芽腫が 最も疑われた。中枢神経系への浸潤や遠隔転移は認めら れなかった。血管塞栓術後, シスプラチン (CDDP) と ピラルビシン (THP-ADR) で治療が開始されたが，家族 の希望で当院転科となった。

(2)症例 : 14歳男児. 左上顎・鼻腔部腫瘍.1990年 1 月左眼球突出飞て近医を受診, 当院入院となった. MRI で左上顎と鼻腔に腫瘍を認めた(図 $1 \mathrm{~A}$ )。入院時
の骨䯣検査で $65 \%$ の異常細胞を認めた(図 $1 \mathrm{~B}$ )。

(3)症例 !:16歳女子. 左頸部腫瘍. 1986年 5 月左頸 部腫瘤にて発症, 前院で横紋筋肉腫を疑われ, VAC 療 法(ビンクリスチン, アクチノマイシン D とシクロフォ スファミド)の化学療法と手術が行なわれた。しかし局 所再発のため, 1991年 4 月当院転科となった。 MRI で は左頸部内頸動脈背外側に腫瘍が認められた(図 2)。当

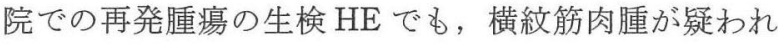
た。

(4)症例 : 12歳男児. 右上顎部腫瘍. 1992年 1 月に 右耳下腺部の腫脹が出現， 2 月に同部位に压痛を認め, 近医を受診，当科に入院となった．初診時右煩部から耳 下腺部にかけて腫脹, 局部の疼痛と開口障害を認め, 右

表 1 頭頸部原発の横紋筋肉腫 4 症例の臨床像

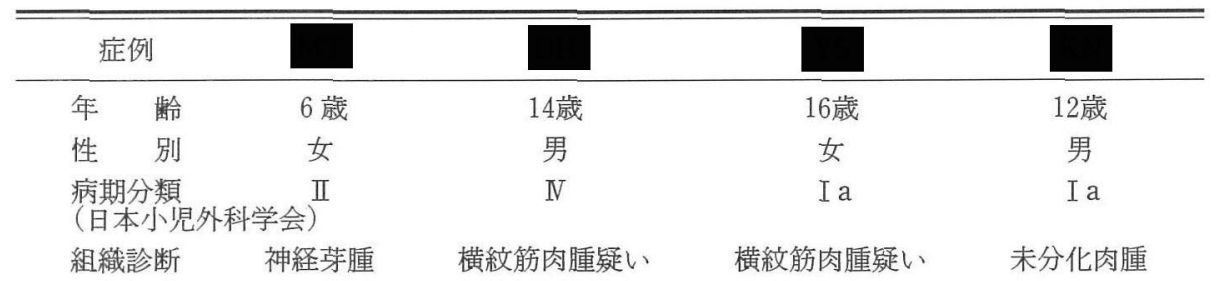
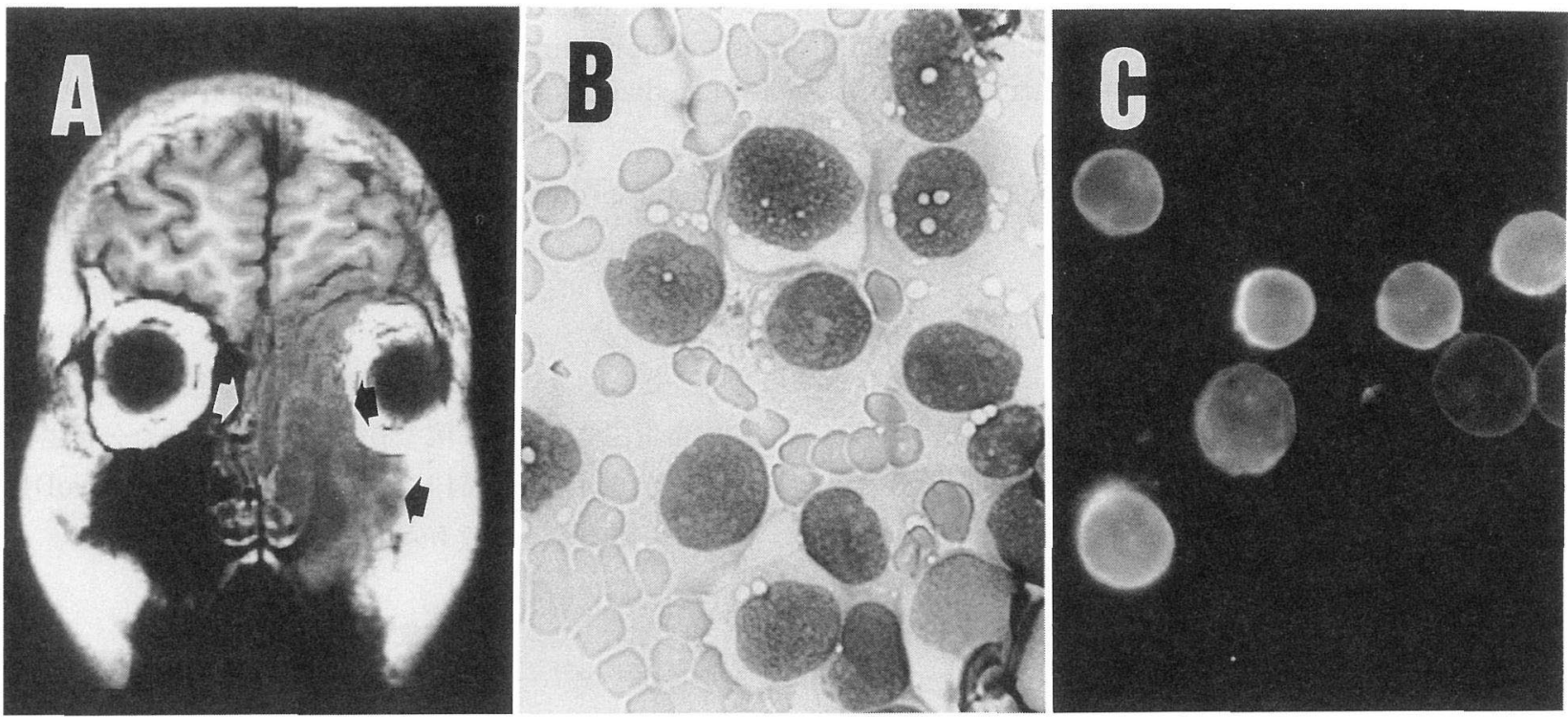

図 1 骨髄転移細胞で横紋筋肉腫と診断可能であった症例 DH の MRI と細胞骨格蛋白の解析

A：MRIで左上顎と鼻腔に矢印で囲まれた腫瘍を認めた.

B：骨䯣検査では $65 \%$ に異常細胞を認めた (1,000倍).

C : 骨髄転移細胞は, desmin と $\alpha$-sarcomeric actin 陽性 (1, 000倍), その他の反応性より横紋筋肉腫と診断. 

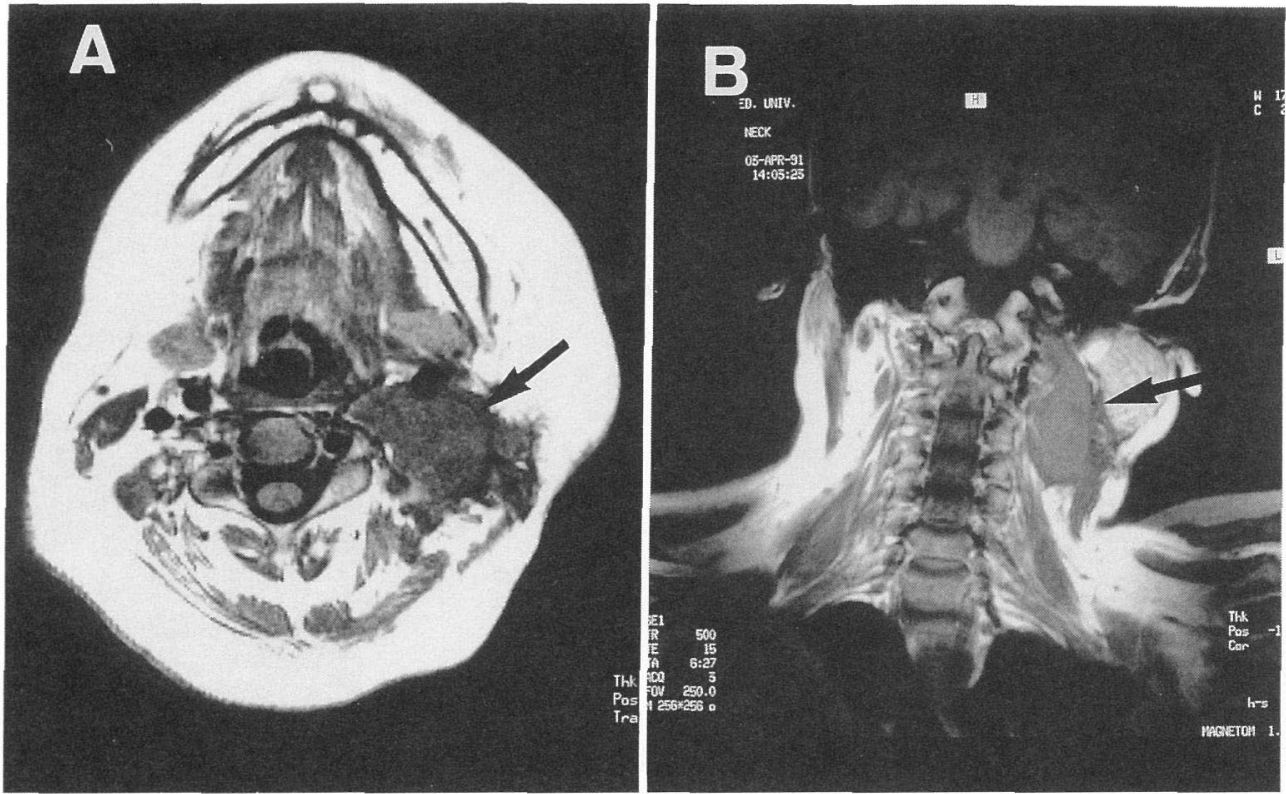

図 2 細胞骨格蛋白の解析で横紋筋肉腫と診断された症例 の頸部腫瘍 A， B : MRI で左頸部内頸動脈背外側に腫瘍を認めた。

煩粘膜には凹凸不整の腫瘍が突出していた，MRIでは 右下䫇骨周辺，耳介下部から脳底部，側頭葉腹側に及ぶ 腫瘍を認めた. 右下顎骨は腫瘍の浸潤で融解していた(図 $3 \mathrm{~A}$ ). 原発腫瘍の生検では, 紡鍾形の腫瘍細胞を認め (図 3 B), PAS 染色陽性の顆粒が腫瘍細胞内に認められ, 未分化肉腫と診断した.

2) 細胞骨格蛋白の解析

我々の研究室で腫瘍細胞の鑑別診断に用いている，細 胞骨格蛋白と細胞質蛋白 (myoglobin) 抗体計 7 種の特異 性と反応性を表 2 亿示す334).

3 ）筋肉分化制御遺伝子 MyoD1 の発現

total RNA を症例 KN の腫瘍組織より guanidine isocyanate cesium chlorideで抽出した. $10 \mu \mathrm{g}$ の total RNA を変成後，ホルムアルデヒドを含む $1 \%$ \%ガロー スゲルで分離, Northern blot 法で MyoD1 遺伝子発現 を検討した。ヒト MyoD1のプローベは, pBluescript $\mathrm{SK}^{+}$からの $1.9 \mathrm{~kb}$ EcoRI full-length cDNA を使用し $\star^{5)}$.

\section{結果}

1) 細胞骨格蛋白と MyoD1 発現の解析

表 3 飞 4 症例の細胞骨格蛋白の解析, MyoD1 発現と
確定診断を示す。

(1)症例 : 生検材料を用いた腫瘍細胞の細胞表面膜 抗原 (KP-NAC8, KP-NAC9, KP-NAC10, HSAN1.2, PI153/3 と CD56 抗体による) の解析で, 神経芽腫は否 定された316)。次に行なった細胞骨格蛋白の解析では, vimentin, desmin, $\alpha$ and $\gamma$-muscle actin $と$ myoglobin が陽性を示し，免疫組織学的に横紋筋肉腫と診断した。 確定診断は, 組織学的所見と合わせ, 胎児型横紋筋肉腫 であった。

(2)症例 : 初診時の骨䯣検査で65\%の異常細胞が認 められた。細胞表面膜抗原の解析では, 白血病・悪性リ ンパ腫と神経芽腫は否定された ${ }^{366)}$. 細胞骨格蛋白の解 析では, vimentin, desmin, $\alpha$ and $\gamma$-muscle actin $之 \alpha-$ sarcomeric actin が陽性で，入院当日に横紋筋肉腫の診 断が可能であった(図 $1 \mathrm{~B}$ と C). 頸部リンパ節転移巣の 生検の組織学的診断は胞巣型横紋筋肉腫疑いであった。 免疫組織学的には, vimentin, desmin, $\alpha$ and $\gamma$-muscle actin と $\alpha$-sarcomeric actin が陽性で横紋筋肉腫と確定 診断した

(3)症例 : 転院後の横紋筋肉腫が疑われた生検材料 で,さらに細胞骨格蛋白の解析を行なった。 その結果, vimentin と myoglobin が陽性を示し, 横紋筋肉腫の確 

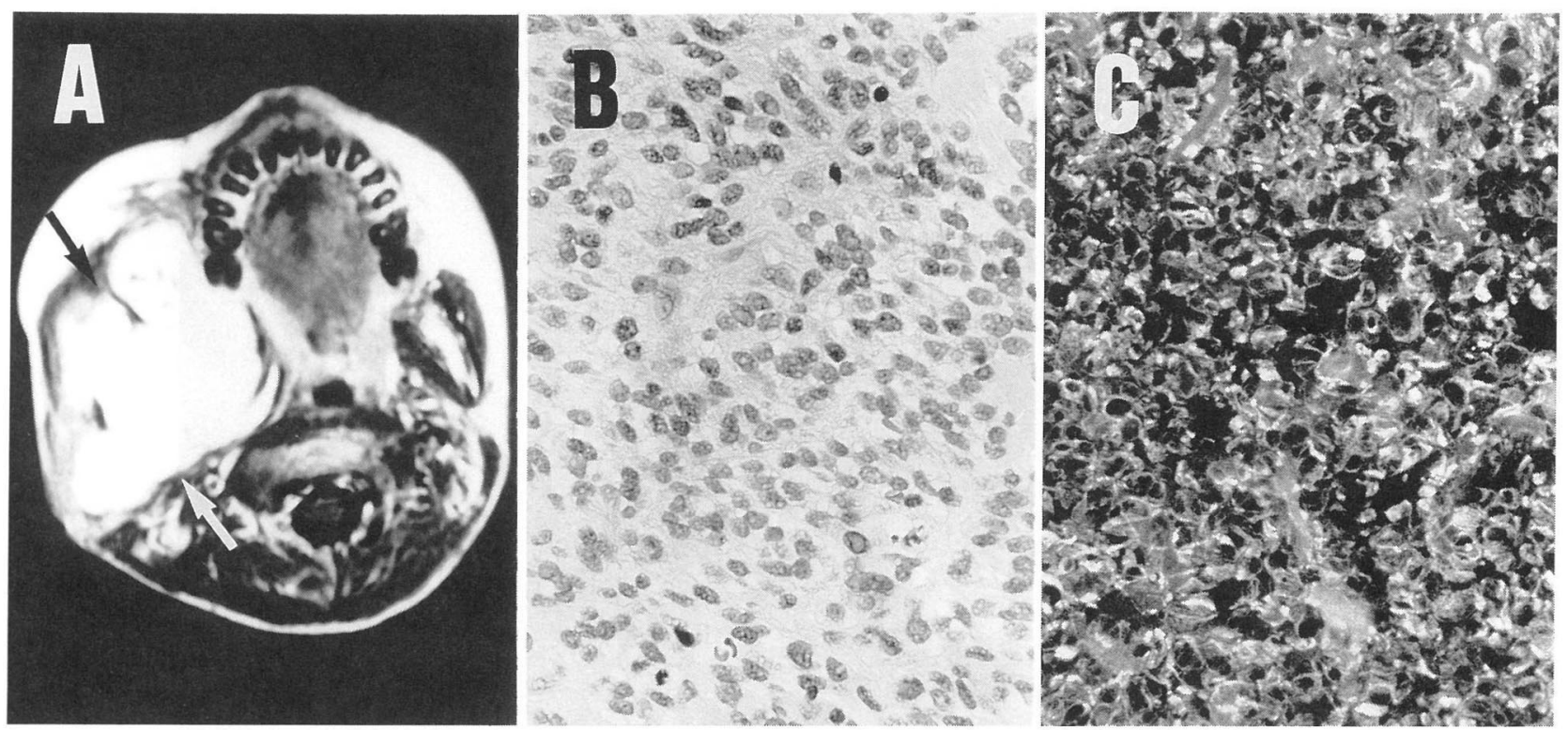

図 3 MyoD1 の発現で未分化横紋筋肉腫と診断可能であった症例

MRI と細胞骨格蛋白の解析

A : MRI で右下顎骨周辺, 耳介下部から脳底部, 側頭葉腹側に及ぶ巨大な腫瘍を認ぬた。

B : 生検腫瘍組織の $\mathrm{HE}$ 染色では, 紡錘形細胞が密に増殖, 未分化肉腫と診断 (400倍).

C : 間接営光抗体法による細胞骨格蛋白の解析では, 腫瘍細胞は vimentin のみ陽性 (400倍).

表 2 細胞骨格蛋白の解析に用いたモノクローナル抗体

\begin{tabular}{lll}
\hline \hline \multicolumn{1}{c}{ 抗体名 } & \multicolumn{1}{c}{ 特 異 性 } & \multicolumn{1}{c}{ 特 異 性 } \\
\hline V-9 & vimentin & 間葉系細胞 \\
DEU-10 & desmin & 骨格筋・心筋・平滑筋細胞 \\
$\alpha$-sr-1 & $\alpha$-sarcomeric actin & 骨格筋・心筋細胞 \\
HHF35 & $\alpha$ and $\gamma$-muscle actin & 骨格筋・心筋・平滑筋細胞 \\
myoglobin & myoglobin & 骨格筋細胞 \\
neurofilament & neurofilament & 神経細胞 \\
K8. 13 & cytokeratin & 上皮細胞
\end{tabular}

定診断が可能となった。

\section{(4)症例}

: 生検腫瘍材料で細胞骨格蛋白の解析をさ らに行なった。その結果，vimentin のみ陽性で(図 3 C), desmin, $\alpha$ - and $\gamma$-muscle actin, cytokeratin, myoglobin と neurofilament はいずれも陰性で，未分化肉腫と診断 した．結局組織学的診断を上回る，細胞骨格蛋白の解析 の結果は，得られなかった。

そこで生検腫瘍組織で筋肉分化制御遺伝子 MyoD1 の 発現を検討した。図 4 に示すように，横紋筋肉腫と診断 された陽性コントロール (RMS1) と本患児の腫瘍組織 (RMS2) で，MyoD1 発現が $2.0 \mathrm{~kb}$ に認められた。.以上
より未分化横紋筋肉腫と確定診断した。

考案

横紋筋肉腫は，小児期の最も頻度が高い軟部組織腫瘍 で，小児悪性腫瘍の 4 〜 \%を占める. その発生母地は， 未分化な骨格筋細胞に由来，腫瘍組織中に骨格筋分化に 対応するさまざまな分化段階の腫瘍細胞が，認められる ことがある。しかし腫瘍細胞の大多数は，いわゆる小円 形細胞腫瘍であり, 神経芽腫, Ewing 肉腫, 悪性リン パ腫などの小円形細胞腫瘍との形態学的鑑別診断が困難 なことが多い3．頡頸部原発の小児悪性腫瘍は，小児悪 
表 3 頭頸部原発の横紋筋肉腫 4 症例の細胞骨格蛋白解析と MyoD1 発現と確率診断

\begin{tabular}{|c|c|c|c|c|}
\hline 症例 & & & & \\
\hline vimentin & + & + & + & + \\
\hline desmin & + & + & - & - \\
\hline$\alpha$-sarcomeric actin & NT & + & - & - \\
\hline$\alpha$ and $\gamma$-muscle actin & + & + & - & - \\
\hline myoglobin & + & NT & + & - \\
\hline neurofilament & - & - & & - \\
\hline cytokeratin & - & - & & - \\
\hline 免疫組織学的診断 & 横紋筋肉腫 & 横紋筋肉腫 & 横紋筋肉腫 & 未分化肉腫 \\
\hline MyoD1 mRNA 発現 & NT & NT & NT & + \\
\hline 確定診断 & 胎児型横紋筋肉腫 & 胞巣型横紋筋肉腫 & 横紋筋肉腫 & 未分化横紋筋肉腫 \\
\hline
\end{tabular}

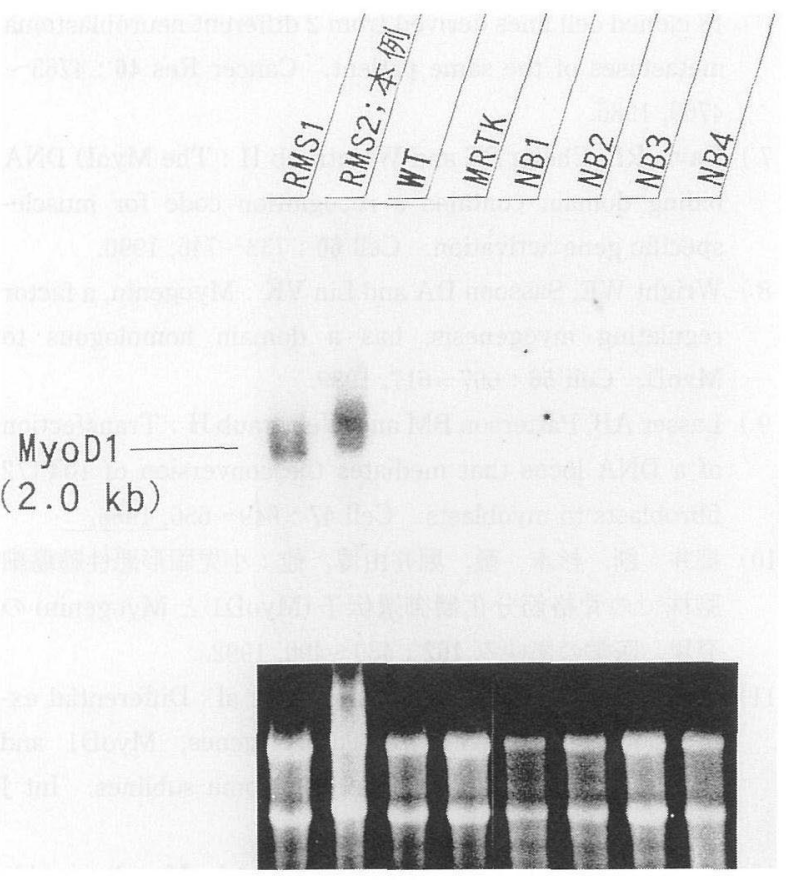

図 4 症例—の腫瘍組織での MyoD1 遺伝子の発現 患児の腫瘍組織 (RMS2) では $2.0 \mathrm{~kb}$ そその発現を認め た．陽性コントロールとして横紋筋肉腫 (RMS1), 陰性 コントロールとして Wilms 腫瘍 (WT), malignant rhabdoid tumor (MRTK), 神経芽腫 (NB1〜4) を用いた。

性腫瘍の約 $5 \%$ を占め ${ }^{1)}$, 横紋筋肉腫, 悪性リンパ腫, 神経芽腫などの悪性腫瘍がある.

我々は, 最近経験した頭頸部原発横紋筋肉腫 4 例の細 胞骨格蛋白と 1 例の筋分化制御遺伝子 (MyoD1) を検討，
鑑別診断への有効性を検討した.

横紋筋肉腫の確定診断は, (1)組織学的に好酸性の豊富 な細胞質と横紋を持つ腫瘍細胞(横紋筋芽細胞)，ぬた (2) desmin, $\alpha$ and $\gamma$-muscle actin, $\alpha$-sarcomeric actin $と$ myoglobin などの筋特異的骨格蛋白の存在を免疫組織学 的に証明することである。しかしすべての横紋筋肉腫の 細胞が，これらの組織学的特徵や筋特異的骨格蛋白を発 現しているわけではない。我々の 4 症例でも, 注意深い 組織学的観察で 1 例(症例 のみで横紋筋芽細胞を認 めることが出来た。

細胞骨格蛋白は, 真核細胞の中に張りめぐらされた線 維状の構造で, 微小管, マイコフィラメントと中間フィ ラメントの 3 種の細胞内線維構造がある. 細胞骨格蛋白 は, 特定の細胞に分布, 細胞の同定または分化のマーカー になりらる。我々は，モノクローナル抗体を用いた細胞 骨格蛋白の解析で, 迅速かつ正確に横紋筋肉腫細胞株と 腫瘍組織の同定が出来ることを報告してきた3)4)，用い た抗体の中では desmin, $\alpha$ and $\gamma$-muscle actin, $\alpha$-sarcomeric actin と myoglobin が, 横紋笳肉腫の鑑別診断 に有効であった。

今回の頭頸部原発横紋筋肉腫 4 症例のうち， 3 症例で 細胞骨格蛋白の解析は有効であった。すなわち症例 【は，前院で神経芽腫と診断されていたが，細胞骨 格蛋白の解析で, 横紋筋肉腫の確定診断が可能となった。 症例】は, 骨骾転移細胞の細胞骨格蛋白の解析で, 入院当日(頸部リンパ節転移の生検結果の 1 週間前)に, 横紋筋肉腫の診断が可能となった。症例—は, 再発腫 
瘍組織の生検で組織学的に横紋筋肉腫が疑われ, 細胞骨 格蛋白の解析で横紋筋肉腫の確定診断が可能となった. しかし症例は, 組織学的検討と細胞骨格蛋白の解 析では未分化肉腫としか診断出来なかった(表 3 ).

近年 MyoD1, myogenin, MRF4 と myf-5 の 4 つの核 蛋白が, 胎生期の多能中胚葉細胞 (mesodermal stem cell) を筋芽細胞 (myoblast), さらに筋管細胞 (myotube) への分化を調節する筋分化制御遺伝子として同定され $た^{7) 8)}$. MyoD1 遺伝子は, 1986年 Lasser $5^{9)}$, Davis $5^{7)}$ により発見された管分化制御遺伝子である. 最近 MyoD1 遺伝子を用いた横紋笳肉腫診断の有用性が，我々10)11), Tonin ら 12) とDias ら 13)により報告されている. そこで 組織学的に未分化肉腫と考えられる, 症例 の腫瘍 組織の MyoD1の発現を検討した. その結果腫瘍組織に MyoD1 mRNA 発現が認められ, 未分化横紋筋肉腫と確 定診断した（図 4 ).

近年腫瘍の診断は，腫瘍細胞の(1)組織学的検討のみな らず，(2)細胞表面膜抗原，(3)細胞骨格蛋白，(4)染色体， (5)DNA・RNA 遺伝子診断などの検討で，一層正確に診 断，また予後の予测が可能になってきた。このため生検 または摘出腫瘍は，そのまま全部をホルマリン固定用の ビン(病理パラフィン切片用)に入れず，種々の検討に用 いることが大切である. DNA・RNA 解析用の検体保存 のため，手術場に液体窒素を持参する必要がある.

以上最近経験した頭頸部原発横紋筋肉腫 4 症例で, 細 胞骨格蛋白と MyoD1 mRNA の解析が，その早期診断 と鑑別診断に有用であった。特に MyoD1 mRNA の解 析は, 従来の方法では診断が困難な未分化横紋筋肉腫の 診断に役立ったことを報告した.

$$
\text { まとめ }
$$

頭頸部原発の悪性腫瘍は，小児悪性腫瘍の約 $5 \%$ を占 め, 悪性リンパ腫, 神経芽腫, 横紋筋肉腫などがある. これらの腫瘍は, 形態学的に小円形細胞腫瘍に分類され, その鑑別診断は困難なことがある．最近我々は，4例の 頭頸部原発の横紋笳肉腫を経験した. 組織学的診断以外 に細胞骨格蛋白を用いた免疫組織学診断が 3 例で有効, また筋分化制御遺伝子 (MyoD1) を用いた分子生物学的 診断が 1 例で有効であった。生検または摘出腫瘍組織の 細胞・分子学的検討の必要性を強調した.

\section{文献}

1) Bonilla JA : Management of malignant head and neck tumors in children. Pediatr Clin North Am $36: 1443 \sim 1450$, 1989.

2 ) 杉本 徹, 沢田 淳 : 小児の頸部腫脹. JOHNS $7: 125$ ～ $129,1991$.

3 ) 杉本 徹, 松村隆文, 堀井由博, 他 : 細胞表面膜抗原, 細 胞骨格蛋白と N-myc 癌遺伝子による小児固形悪性腫瘍の 診断と問題点. Hum Cell $5: 1 \sim 11,1992$.

4) 杉本 徹, 細井 創, 峯 宏, 他: 横紋筋肉腫の細胞・ 分子生物学的診断. 小児科 $34: 105 \sim 116,1993$

5 ) Scrable HJ, Johnson DK, Rinchik EM, et al : Rhabdomyosarcoma-associated locus and MyoD1 are synteric but separate locus and short arm of human chromose 11. Proc Natl Acad Sci 87 : 2182 2186, 1990.

6 ) Sugimoto T, Sawada T, Matsumura T, et al : Identical expression of cell surface membrane antigens on 2 parent and 18 cloned cell lines derived from 2 different neuroblastoma metastases of the same patient. Cancer Res $46: 4765 \sim$ 4769, 1986.

7 ) Davis RL, Cheng PE and Weintruab H : The MyoD DNA biding domain contains a recognition code for musclespecific gene activation. Cell $60: 733 \sim 746,1990$.

8 ) Wright WE, Sassoon DA and Lin VK : Myogenin, a factor regulating myogenesis, has a domain homologous to MyoD. Cell $56: 607 \sim 617,1989$.

9 ) Lasser AB, Patterson BM and Weintraub $\mathrm{H}$ : Transfection of a DNA locus that mediates the conversion of $10 \mathrm{~T} 1 / 2$ fibroblasts to myoblasts. Cell $47: 649 \sim 656,1986$.

10）細井 創, 杉本 徹, 堀井由博, 他 : 小児固形悪性腫瘍細 胞株での骨格筋分化制御遺伝子 (MyoD1 と Myogenin) の 発現. 医学のあゆみ $162: 489 \sim 490,1992$.

11) Hosoi H, Sugimoto $T$, Hayashi $Y$, et al : Differential expression of myogenic regulatory genes, MyoD1 and myogenin, in human rhabdomyosarcoma sublines. Int $\mathrm{J}$ Cancer $50:$ 977 983, 1992.

12) Tonin PN, Scrable H, Shimada $H$, et al : Muscle-specific gene expression in rhabdomyosarcoma and stages of human fetal skeletal muscle development. Cancer Res $51: 5100 \sim 5106,1991$.

13) Dias P, Parham DM, Shapiro DN, et al : Myogenic regulatory protein (MyoD1) expression in childhood solid tumors. Am J Pathol $137:$ 1283 1291, 1990.

$$
\left.\begin{array}{l}
\text { 原稿受付 : 平成 } 7 \text { 年 } 6 \text { 月 } 8 \text { 日 } \\
\text { 原稿採択 : 平成 } 7 \text { 年 } 8 \text { 月 } 3 \text { 日 } \\
\text { 別刷請求先 : 杉本 徹 } \\
\text { T } 889-16 \text { 宮崎県宮崎郡清武町大字木原 } 5200 \\
\text { 宮崎医科大学小坚科学教室 }
\end{array}\right)
$$

